Teosofia: Indonesian Journal of Islamic Mysticism, Vol. 10, No. 2, 2021, pp. 161-176

e-ISSN: 2540-8186; p-ISSN: 2302-8017

DOI: $10.21580 /$ tos.v10i2.10054

\title{
SUFISM AND PANDEMIC: \\ Lesson Learned from Sufi Teachings and its Prominent Figures
}

\author{
M. Nur Kholis Setiawan \\ Faculty of Ushuluddin, Adab and Humanities \\ Universitas Islam Negeri Prof. K.H. Saifuddin Zuhri Purwokerto, Indonesia \\ mnkholissetiawan@kemenag.go.id
}

Article history: Received: 7 October 2021; Accepted: 10 December 2021; Published: 20 December 2021

\begin{abstract}
:
Religious perspective is an important aspect to be used in dealing with the COVID-19 global pandemic and the Islamic one is not an exception. It is Sufism that concerns more on the spiritual dimension of Islam that might be taken into consideration. Based on several books on Sufi scholars and teachings, such as al-Isfahani's Hilyat al-Auliyā', wa-țabaqāt al-Aṣfiyā, al-Attar's Tadhkirat al-Auliyā, al-Sakandari's al-Hikam, and others, this article proposes Sufi teachings as inevitable tools in facing the pandemic. Using content analysis, intertextuality, and historical approaches, this paper concludes how Sufism with its basic teachings such as 'uzlah, șumtu, qanā'ah, shukr, et cetera, will be the suitable elements for Muslims to face and overcome the pandemic. Several prominent Sufi scholars will also be used to strengthen the argument.
\end{abstract}

Keywords: intertextuality; overcome; pandemic; prominent figures; sufism

\section{A. Introduction}

Tt has almost been two years that the COVID-19 global pandemic has ceaselessly impeded human daily life. All social, economic, and political sectors, starting from attending schools, universities, markets, public policies, to celebrating at in-person social gatherings are gripped by the pandemic lockdowns. The Covid-19 has changed many things, killed many people, and ended parties. ${ }^{1}$ Many efforts have been done by people and the government as a response to the pandemic such as promoting healthy protocols, physical and social distancing, online education, work from home, a restrictive form of lockdown, vaccination program, etc. ${ }^{2}$

1 Daniela Klimová et al., “COVID-19 Pandemy-The Global Challenge," Lekarsky Obzor 69, no. 4 (2020): 102-6, https:/www.lekarsky.herba.sk/index.php/2020/279-lekarsky-obzor-4-2020/867pandemia-covid-19-celosvetova-vyzva.

2 Dyah Febriani, Valeryan Bramasta, and Vanissa Noorizqa, "Evaluation of Government Policy Readiness in the Management of the Covid-19 Pandemy Viewed From the Implementation of Dynamic Governance," Research Gate, no. April (2020), https://www.researchgate.net/publication/340808905_Evaluation_Of_Government_Policy_Readines s_In_The_Management_Of_The_Covid-

19_Pandemy_Viewed_From_The_Implementation_Of_Dynamic_Governance. 
Not all efforts were well responded to by religious adherents. Several Muslim groups in the beginning spread of the pandemic were not able to understand the Covid19 as a threat. So, they sometimes broke some policies. Many of them ignored physical distance in their religious activities such as Jum'ah (Friday) prayer and religious meetings. ${ }^{3}$ It means that some people were not aware of the Covid-19 global pandemic. ${ }^{4}$ They argued that it bothered either their social-economic or religious activities. The pandemic should not stop them from normal activities in which its abnormal could cause slowing down of economic lives. ${ }^{5}$

There are other several related previous studies to this research. However, research on the response of the Muslim community to the COVID-19 pandemic is more of a field study of the Muslim community at a particular locus. ${ }^{6}$ Many of these studies have also been carried out using a quantitative analysis approach. In general, they want to build an argument that religion, Islam, has contributed to the creation of Muslim community resilience in the face of the COVID-19 pandemic. ${ }^{7}$ Meanwhile, qualitative research reports that there has been deauthorization of ulama in Indonesia due to their response to the COVID-19 issue which was not received sympathetically by the public. ${ }^{8}$

Those phenomena told us about how religious awareness played both positive and negative roles in responding to the Covid-19 pandemic. On the positive side, religion helps with coping with stress, uplifts peoples' spirits in times of hardships, and provides values to practice as faith-based healing. On the other hand, religion can have negative influences on public health as the example mentioned above.

3 Several media narrated responses of the religious leaders regarding the Covid 19. Some of them are in the opinion that the covid 19 is a global conspiracy. See for example, Sastra Yudha, "Tilik Respon Awal Pemuka Agama Terhadap Covid-19 Bersama STF," http://rdk.fidkom.uinjkt.ac.id/, July 2, 2021, http://rdk.fidkom.uinjkt.ac.id/index.php/2021/07/02/tilik-respon-awal-pemuka-agamaterhadap-covid-19-bersama-stf/. accessed on October 16, 2021.

4 Mohammad Hidayaturrahman et al., "Religious Behavior of Indonesian Muslims as Responses to the Covid-19 Pandemic," Al-Adabiya: Jurnal Kebudayaan Dan Keagamaan 16, no. 1 (2021), https://doi.org/10.37680/adabiya.v16i1.704.

5 Hasan Bisri, "Religious Community Responses to COVID-19: Case Study on Muslim Small Community," International Journal of Psychosocial Rehabilitation 24, no. 8 (2020): 10439-46, https://doi.org/10.37200/IJPR/V24I8/PR281038; Riyanti Djalante et al., "Review and Analysis of Current Responses to COVID-19 in Indonesia: Period of January to March 2020," Progress in Disaster Science 6 (April 2020), https://doi.org/10.1016/j.pdisas.2020.100091.

6 Justin Thomas and Mariapaola Barbato, "Positive Religious Coping and Mental Health among Christians and Muslims in Response to the Covid-19 Pandemic," Religions 11, no. 10 (2020): 1-13, https://doi.org/10.3390/rel11100498.

7 Abdurrohman Kasdi and Saifudin, "Resilience of Muslim Families in the Pandemic Era: Indonesian Millennial Muslim Community’s Response Against COVID-19," Jurnal Penelitian 17, no. 1 (2020): 81-94, http://e-journal.iainpekalongan.ac.id/index.php/Penelitian/article/view/2781.

8 Mustaqim Pabbajah et al., "Deauthorization of the Religious Leader Role in Countering Covid- 19: Perceptions and Responses of Muslim Societies on the Ulama's Policies in Indonesia," International Journal of Criminology and Sociology 9 (2020), https://doi.org/10.6000/1929-4409.2020.09.25. 
This writing proposes Sufi teachings as a vehicle in facing the pandemic. Sufism has been one of the Islamic teachings which are important in Muslim society. It deals with the spiritual aspect of life. ${ }^{9}$ Its teaching is numerous starting from the easiest to complicated ones. Its goal for Muslims is to achieve the so-called ma'rifatullāh.

There are a lot of sources written by scholars in this regard. We need to compare one source to another to find out how numerous the Sufi teachings which are useful to deal with the Covid-19. Using intertextuality ${ }^{10}$ and content analysis ${ }^{11}$ on several books on Sufi teachings and prominent Sufi figures, this article will be able to depict their significant aspects to facing the pandemic. In addition to both methods, the analysis of the Sufi figures will use a historical perspective to get its significance to this paper's topic.

\section{B. Teachings of Sufism}

Islam has Sufism tradition. Sufism understands religion based on the ethical dimensions rather than the ceremonial ones. To face the real threat of the Covid-19 is to face with ethical dimensions of religion. ${ }^{12}$ Islamic Sufism has many practices that help people to cut the spreading of the Covid-19. Among those practices are 'uzlah, sumt $u$, and $q a n \bar{a}$ ' $a h .{ }^{13}$

'Uzlah is avoiding a crowd and contact with other people. By doing 'uzlah, automatically, people do not have any direct physical contact with others which means keeping distance from others. In this regard, Arifin has examined 'uzlah among Santri communities in Islamic boarding schools (pesantren). ${ }^{14}$ While Sumtu means keep

9 Muh. Mustakim, Kana Safrina Rouzi, and Tumin Tumin, "Spiritualization of Child Education in the Qur'anic Sufism Perspective in the Covid-19 Era," International Journal of Islamic Educational Psychology 2, no. 1 (2021), https://doi.org/10.18196/ijiep.v2i1.11132.

10 Intertextuality is the shaping of a text's meaning by another text. It is the interconnection between similar or related works that reflect and influence an audience's interpretation of the text. It is a tool of reading and comparing texts that creates an 'interrelationship between texts' and generates related understanding in separate works. For more deteil on this method, see Julia Kristeva, Desire in Language: A Semiotic Approach to Literature and Art (Colombia: Columbia University Press, 1980).

11 Content analysis is the study of documents or communication artifacts, which might be texts of various formats. Scientists use content analysis to examine patterns in communication in a replicable and systematic manner. In this paper, content analysis is used to analyse various teachings of sufism and the exemplification of the sufi figures. For more detailed on this method, see, Klaus Krippendorf, Content Analysis: An Introduction to Its Methodology, 2nd ed. (Thousand Oaks, CA: Sage, 2004).

12 Sabrida Muhammad Ilyas, "Islamic Psychotherapy In The Pandemic Of Covid-19," ENLIGHTEN (Jurnal Bimbingan Dan Konseling Islam) 3, no. 1 (2020), https://doi.org/10.32505/enlighten.v3i1.1581.

13 For more details on those teachings several following books might be usefull, Ibn Athaillah AlSakandari, Lațā 'if Al-Minan, ed. Abd al-Halim Mahmūd (Beirut: Dār al-Mina, 2007); Abu Hāmid Al-Ghazālī, Minhāj Al-'Abiđīn Ilā Jannati Rabb Al-'Alamīn (Cairo: Dār al-Minhāj, 1998); Ihsan Muhammad Dahlan Al-Jampesi, Sirāj Al-Ṭa libìn (Beirut: Dar al-Fikr, 2002).

14 Samsul Arifin and Akhmad Zaini, "Decision of Implementing Uzlah and Gerbat Techniques in Islamic Boarding School as Preparedness Response for Covid-19 Pandemic," Unnes Journal of Public Health 9, no. 2 (2020), https://doi.org/10.15294/ujph.v9i2.38107. 
staying and silent. Stay is not going anywhere, and silence is not commenting the vain thing. Qanā 'ah means awareness to accept reality. It is the concept of attitude toward material provision and worldly sustenance. ${ }^{15}$

The definition of 'uzlah in the Sufism tradition, according to al-Hikam, is to do tafakkur, think, digest the phenomena of Allah's creation with whole-souled. ${ }^{16}$ Totality in tafakkur which merely to glorify Allah's names (Asmā' Allāh) and underestimate all His creations will bring optimism in facing the Covid-19 pandemic. In the context of Sufism, pandemics are equated with creatures, so there is no need to respond to them with excessive fear.

Silence in Sufism has also its own significance. Silence means being efficient by not communicating and interacting directly with others. ${ }^{17}$ Keeping silent has an impact on reducing the potential for virus transmission. In this context, silence is golden. Avoiding the negative impact that may arise from direct face-to-face communication with silent activities is in line with the government's policy on social distancing.

Meanwhile, qanā 'ah, accepting what it is, is also a very important means. This attitude is a blessing for all accidents that occur, whatever the conditions. The result of applied $q a n \bar{a}$ ' $a h$ is that if someone succeeds in his/her efforts, it does not make him/her easy to be takabbur (pride). On the contrary, when failure happens, he/she is not easy to despair. This kind of character makes a person very healthy psychologically as well as the basic capital of a person's optimal role in society.

The attitude of $q a n \bar{a}$ ' $a h$ is also a medicine for the heart in order not to be easily trapped in greed. The absence of a greedy attitude in someone will make him have more empathy for others. This is reinforced by not being miserly to share. In the context of the movement against the pandemic, the government certainly cannot afford it alone. Community support is a necessity. A sālik (a spiritual traveler in Sufism) ${ }^{18}$ who makes qanā 'ah as his attitude is the best factor for the success of the joint movement against the Covid-19 pandemic.

In addition to the described teachings in Sufism, there are also known steps of a sā lik to get closer to Allah. These stages are takhalli, tahalli, and tajalli. ${ }^{19}$ All three are stages of a Sufi as an effort to cleanse oneself, draw closer to Allah and get the blessings of ma'rifat.

15 Mohammed Farid Ali, “Contentment ( Qanācah ) and Its Role in Curbing Social and Environmental Problems," Islam and Civilisational Renewal 5, no. 3 (2014): 430-45, https://doi.org/10.12816/0009871.

16 Ibn Athaillah Al-Sakandari, Al-Hikam (Beirut: Dar al-Fikr li 1-Tiba'a wa 1-Nasyr, 1987), 16.

17 Christopher Braddock, "Silence Will Change the World: Kierkegaard, Derrida and Islamic Sufism," in The Philosophy of Spirituality (Brill, 2019), 189-208, https://doi.org/10.1163/9789004376311_012.

18 Awis Karni, “Al-Tasawwuf Fî Indûnîsiyâ; Dirâsah Li Nuskhah Kitâb Matâlib Al-Sâlikîn Ta'lîf Yûsuf Al-Makâsârî,” Studia Islamika 3, no. 2 (1996), https://doi.org/10.15408/sdi.v3i2.810.

19 Haidar Putra Daulay, Zaini Dahlan, and Chairul Azmi Lubis, "Takhalli, Tahalli Dan Tajalli," Pandawa 3, no. 3 (2021): 348-65, https://doi.org/10.36088/pandawa.v3i3.1334. 
Takhalli is the stage where a sālik cleanses himself of bad qualities, despicable and immoral actions that pollute the heart of a sā lik. These traits include jealousy and envy, prejudice, pride, showing off, being short-tempered, self-centered, selfish, easy to blame others, and so on.

The prohibition to have qualities that are not commendable for a sālik makes him a proportional individual in his role in society. The distance of uncommendable traits makes a sālik able to become an influencer related to the still uncontrolled Covid- 19 pandemic. The existing movement to minimize the transmission of the Covid-19 virus driven by the government can work more effectively by involving sālik in the world of Sufism and thariqah.

A sālik will perform the next stage, namely tahalli, after being able to cleanse himself of all attitudes and actions that are not commendable. This stage is selfdecoration with noble qualities, commendable character. All aspects of his life are decorated with positive deeds that not only have an impact on self-pity but also social piety. This social piety influences a conducive atmosphere for social order and society.

The emergence of social piety in a person, of course, will be very positive if it is associated with a joint movement against the pandemic. The willingness to help, concern for others and the empathy possessed by a sālik become one of the important forces for the dissemination of the joint movement. The sālik is easy to become a volunteer and influencer in the community as strategic partners of the government in disseminating the public awareness movement against the pandemic.

The third stage is tajalli. In the view of the Sufi scholars, such as Ibn al-'Arabi, tajalli is the revelation of the divine light into the heart. The Sufis believe that one can gain the radiance of divine light after abandoning despicable qualities and practicing noble qualities. ${ }^{20}$

The presence of the radiance of divine light into the heart of a sālik will make him more empathetic and more socially sensitive. His siding with the community, no longer individualistic, made him a role model in the community movement against the pandemic.

In addition to the principal teachings on Sufism, Islam also emphasizes the importance of cleanliness and clean living. A very popular jargon in Islam is "cleanliness is part of the faith". With the clean living behavior that is owned by the community and supported by the examples of the Sufis with their various teachings, the success of the movement against the Covid-19 pandemic is more to be expected. Yes, clean living behavior can be expected to eliminate the rate of virus transmission, at the same time, the pandemic reminds us of the substance of Islamic teachings, to always be able to maintain cleanliness.

20 Bambang Irawan, Ismail Fahmi Arrauf Nasution, and Hywel Coleman, "Applying Ibn 'Arabī’s Concept of Tajallī: A Sufi Approach to Environmental Ethics," Teosofia: Indonesian Journal of Islamic Mysticism 10, no. 1 (2021), https://doi.org/10.21580/tos.v10i1.7204. 
It is still related to the teachings of Sufism which is no less important to restore the consciousness of mankind as religious beings. Teachings to be patient $(s a b r)^{21}$ surrender to Allah (tawakkal) love to God (mahabbah), ${ }^{22}$ and various other forms of submission $^{23}$ are the pillars of the community's strength to face the pandemic.

$S a b r$, patience, brings people not to easily complain, especially when they are provoked by hoax news. It will train someone to be wiser in accepting situations, including when they are hit by a pandemic, which in turn will strengthen a person's maturity in interacting with the community. Likewise, a patient person will have the physical and mental strength to face various trials from Allah. With full confidence, a patient person always declares that he is a creature, on the other hand, the pandemic that is hitting is also a creature. Therefore, patient people have better endurance than those who are short-tempered.

Concerning combating the Covid-19 pandemic, patience is very important regarding the attitude of not being easily tempted to travel during the pandemic when there are no urgent necessities. Compliance with health protocols, a clean living culture are keys to reducing further spread of the Covid-19 pandemic. In this regard, obedience clearly requires patience, especially patience for keeping stay at home for safety reasons.

Tawakkal, surrender to Allah, is a teaching that strengthens self-confidence not to be excessively afraid of the pandemic. Death is God's secret for any of His servants whose time will definitely come. Amid the news that there is always death every day, when a person has put his trust in Allah, psychologically he will be calmer. Calm, surrender, and trust in God actually have an impact on strengthening the body's immune power which in turn will make a person more healthy.

In the perspective of Sufism, one will get more love for Allah due to his/her submission, tawakkal, and patience. Love or mahabbah in the Sufi world brings a person to be fearless and psychologically become a truly healthy person. Mental health in turn will strengthen physical endurance. A healthy soul will make us physically healthy. In this regard, there is a significant relationship between Sufi values and mental-physical health for an individual. When these Sufistic teachings are cultivated in social life, people will be more resistant to the Covid-19 pandemic.

21 Kamarudin Salleh et al., "Resilience and Patience (Sabr) in Islamic View When Observing the Movement Control Order (MCO) during the Covid 19 Pandemic," International Journal of

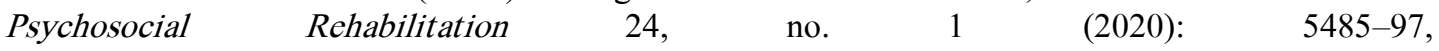
https://doi.org/10.37200/IJPR/V24I1/PR200654.

22 Ach Maimun, "Mahabbah Dalam Tasawuf Rabi 'ah Al-Adawiyah," Millah 3, no. 2 (2004): 172-87, https://journal.uii.ac.id/Millah/article/view/7018.

23 Khairunnas Rajab, "Maqam Dan Al-Ahwal Dalam Tasawuf," Usuluddin 25 (2007): 5-6, https://ejournal.um.edu.my/index.php/JUD/article/view/5078; Ayis Mukholik, "Human Spirituality Phases in Sufism:The Study of Abu Nasr Al-Sarraj in The Book of Al-Luma,", Teosofia: Indonesian Journal of Islamic Mysticism 6, no. 1 (June 15, 2017): 21-32, https://doi.org/10.21580/tos.v6i1.1699. 


\section{Sufi Figures}

This section will show several Sufi figures with their own character. What is meant by self-character is information about prominent traits in their Sufi life that can serve as role models for the current generation in the success of the mass movement against the Covid-19 pandemic. The personal information of the Sufis is taken from two authoritative sources; the first is Fariduddin al-Attar's writing entitled Tadhkirāt al-Auliy $\bar{a}$, and the second is the work of Abu Nu'aim al-Isfahani entitled Hilyat alAuliyā wa-Ṭabaqāt al-Aṣfiyā'.

The exemplary segment of the Sufis from these two authoritative sources is intended to strengthen the legitimacy of Sufi teachings as a tool against the pandemic. If it is only teaching, then the implication is only normative, on the contrary, teaching by involving its representative figures makes the norm have significance in the real world.

The daily characters of the Sufis and the number of prominent figures are so numerous so that it is impossible to take all of them in this limited paper. For this reason, considering the relevance of some norms of Sufi teachings that have been described previously, the following section limits four Sufi characters and their relevant examples to the context of the community movement against the pandemic. They are i) self-correction; ii) selfless and keep learning; iii) cheerful and joke; iv) friendly to take hints

\section{Self-Correction}

Sufi figures are known as persons who are reminded by God when have done mistakes or wrong things. Sufis, because they are still human, sometimes also feel ' ujub and consider themselves to be better than others. Because of their piety, Allah gave them a warning so that they would not repeat the same mistake that causes heart diseases which are complicated and seem trivial, but can interfere with their piety status in front of God.

One example that can be given is a story of Habib al-'Ajami and al-Hasan alBasri, Sufi figures in Basrah which is written in Tadzkirat al-Auliyā, page 85-86, as follows: ${ }^{24}$

$$
\begin{aligned}
& \text { حكى أن الحسن كان مارا على باب صومعة حبيب وقد أذن للمغرب واشتغل حبيب بصلاة } \\
& \text { المغرب، فدخل الحسن وأراد أن يقتدى به فسمع أنه قرأ الهمد لله مقام الحمد لله فلم يقتد به } \\
& \text { وصلى منفردا، فرأى فن تلك الليلة أله تعالى في المنام، قال يا ربى في أي شيء رضاك؟ قال } \\
& \text { أله: يا حسن قد وجدت رضائ وما عرفت قدره، قال: كيف يا ربى؟ قال أله تعالى: لو }
\end{aligned}
$$

24 Faridudin Al-Attar, Tadzkirat Al-Auliya, trans. Muhamad al-Asili al-Wasțāni Al-Syafi'i (Tehran: Markaz Tahqiqat Kutub li-Ulum 1-Islami, 2008). 


$$
\text { ولكن سقت خلف حبيب لأدركت رضائ، وكانت تلك الصلاة خيرا لك من صلواتك في عمرك }
$$

Lhukiya anna l-ḥasan kāna mārran 'alā bābi șaumi'ati habìb, wa-qad udzdzina lil-maghribi wa-isytaghala ḥabìbun bi-ṣalāti l-maghribi, fadakhala al-h̆asan wa-arā da an-yaqtadiya bihi fa-sami'a annahu qara'a alhamdu lillāhi maqāma al-ḥamdu lillāhi fa-lam yaqtadi bihi, wa-șalla munfaridan, fa-ra'ā fi tilka al-lailati allāha ta'āla fi l-manāmi, qāla: yō rabbī fi ayyi syai'in rị̣āka? Qāla Allāhu: yā ḥasan wa-qad wajadta rị̂̄ā î, wa-mā 'arafta qadrahu, qāla: kaifa yō rabb? Qāla Allāhu ta'āla: law șallaita khalfa habìbin la-adrakta rị̣ā $\mathfrak{l}$, wa-kānat tilka l-ṣalātu khairan laka min șalawātika fi 'umrika, wa-lākin saqama 'ibādatuka munfakkatun 'an șịh atin-niyyati]

The free description instead of the translation, as well as the quote from the paragraph above, explains that one day, al-Hasan al-Basri, a Sufi figure, visited Habib al-'Ajami's house, and it happened to be sunset time.

When it was time for the Maghrib prayer, al-Hasan al-Basri was about to perform a congregation of prayers, he heard Habib al-'Ajami's recitation of the Qur'an not being comfortable because the recitation of the letters was not fluent. Habib said the letter al-Fatihah, al-hamdu with the letter $\boldsymbol{h}$, not $\boldsymbol{h}$, then al-Basri resigned himself to the congregation to Habib, on the contrary then al-Basri prayed maghrib alone.

At night, al-Basri dreamed of meeting God, and asked Him, "O Lord, where is Your pleasure in me?" God replied: "You have found My pleasure but you do not realize it". Al-Basri asked again: "how could it be, O Lord, that I didn't realize it?" God replied: "if you pray behind Habib al-'Ajami, you will surely find My pleasure, that prayer is the best prayer compared to your prayers during your life, but you are influenced by your intentions of worship [by belittling the recitation of Habib al-"Ajami's prayer."]

Being reprimanded when someone is mistaken or made a mistake is often found in the stories of the Sufis. This shows that Sufi figures have a close relationship with Allah, so that being mistaken would not be repeated. This warning also reminds Sufi leaders that heart diseases, such as ' $u j u b$, riyā, feeling close to Allah, and so on are not simple diseases. Sufis must be careful not to fall into such heart disease.

The movement to fight the pandemic requires leaders, community leaders who are not allergic to criticism. Each member of the community is also expected to stay away from heart diseases, such as jealousy, feel the most self-righteous, easily blame others, and always have excessive suspicion.

Such mental illness is a serious obstacle in building harmony in society. For this reason, a continuous awareness process is needed so that each member of the community based on religious-spiritual norms can avoid heart diseases, as well exemplified by Sufi figures. 


\section{Selfless and Keep Learning}

A character named Bakr ibn Abdullah al-Muzani is called by the author of Hilyat al-Auliyā as a person who is thirsty for learning, likes to advise others, intelligent, and confident. ${ }^{25}$ Bakr bin Abdullah al-Muzani became important as one of the Sufi figures for the example of the movement against the pandemic because of his unique inherent character, namely acting selflessly, as well as representing a Sufi figure who has a lot of wealth.

The general public believes that people who study Sufism are people who stay away from the world because many studies have analyzed Sufi vocabulary derived from șufah [wool cloth] which reflects simplicity. In ancient times, in classical Islamic civilization, wool was a symbol of simplicity, compared to other types of fabric.

Hundreds of figures are mentioned in the literature of Sufi figures, the fact is simple, away from worldly luxuries. In addition, the teachings of the tariqa also many recommend 'uzlah, stay away from the world.

The figure of Bakr bin Abdullah al-Muzani is a representation of Sufism that does not prevent a person from having luxury, only an attitude to be modest and not limit himself in association with the public, especially the poor, making al-Muzani a character worthy of being a role model.

He is also known as a person who is consistent with the prayers that are said as a form of total submission to the Most Rich. This phrase is written in the Hilyat alAuliyā ${ }^{26}$ according to the narrative of al-Mubarak bin Fadlalah who said as follows:

$$
\begin{aligned}
& \text { سمعت إبن عبد الله المزنى يدعو بهذا الدعاء لا يدعه: أللهم إفتح لنا من خزائن رحمتك رحمة } \\
& \text { لا تعذبنا بعدها أبدا في الدنيا والأخرة ومن فضلك الواسع رزقا حلالا طيبا لا تفقرنا بعده } \\
& \text { المى أحد سواك أبدا تزيدنا لك بكما شكرا وإليك فاقة وفقرا وبك عن من سواك غنيا وتعففا }
\end{aligned}
$$

[I heard Abu Bakr bin Abdullah Al Muzani pray with this prayer, he never left it: 'O Allah, open for us the treasuries of Your mercy, so that You do not punish us after that forever in this world and the hereafter, and from Your vast fadhilah, lawful and good sustenance, which does not make us need anyone other than You forever, which makes us even more grateful to

25 A full description of Bakr ibn Abdullah al-Muzani can be found in Abu Nu'aim Al-Isfahani, Hilyat Al-Auliya Wa-Tabaqat Al-Asfiya, vol. II (Beirut: Dar al-Fikr li 1-Tiba'a wa 1-Nasyr wa 1-Tawzi, 1996), 224-32.

26 Al-Isfahani, II:224.

Teosofia: Indonesian Journal of Islamic Mysticism, Vol. 10, No. 2, 2021 
You with all of that. To You we complain of poverty, and with- You we feel enough so that we need no other than You'.]

The testimony about Bakr bin Abdullah al-Muzani, with the consistency of prayer as described above, is a rich Sufi figure delivered by a character named Amr bin Ali. Amr bin Ali heard directly from Umar bin Ali who tells the following: ${ }^{27}$

$$
\text { كانت قيمة ثباب بكر إبن عبد الله أربعة آلاف وكان يجالس الفقراء والمساكين يحدثهم }
$$

kānat qìmatu tsiyābi bakr ibn abdillāh arba 'ata à lā fin, wa-kāna yujā lisu alfuqarā'a wa l-masākīni yuhadditsuhum, wa-yaqūlu innahu yu'jibuhum dzā lika

[The price of Bakr bin Abdullah's clothes was four thousand, but he used to sit with the poor and chat with them, and he said that it was pleasing [to amaze] them.]

The wealth owned by Bakr al-Muzani did not prevent him from associating with the poor and needy, so the existence of his wealth became wasilah that he helped many people in need.

Besides being generous and selfless in helping, Bakr al-Muzani is also known as a person who is thirsty to learn kindness from others. He does not feel better than others, on the contrary, always puts himself as a person who is less good in front of others. As in Hilyat, it is narrated as follows: ${ }^{28}$

$$
\begin{aligned}
& \text { قال سهل إبن أسلم: كان بكر إبن عبد الله إذا رأى شيخا قال: هذا خير منى عبد الله قبلى، } \\
& \text { وإذا رأى شابا قال: هذا خير منى إرتكبت من الذنوب أكثر من ما إرتكب، وكان يقول: }
\end{aligned}
$$

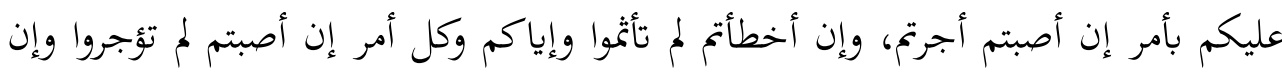

$$
\begin{aligned}
& \text { أخطأتم أثتمه، قيل ما هو؟ قال: سوء الظن بالناس فإنكم لو أصبتم لم تؤجروا وإن أخطأتم }
\end{aligned}
$$

qā la sahl ibn aslam: kāna bakr ibn 'abdillāh idzā ra'ā syaikhan qāla: hā dzā khairun minni 'abada allāha qabî, wa-idzā ra'ā syābbān qāla: hādzā khairun minnī irtakabtu min al-dzunūb aktsara min-mā irtakaba, wa-kāna yaqūlu: 'alaikum bi-amrin in așabtum ajartum wa-in akhța'tum lam ta'tsamū, wa-iyyākum wa-kulla amrin in așabtum lam tu'janū wa-ina akhța'tum atsimtum, qūla mā huwa? qāla: sū'u z-Ẓonni bi l-nāsi fainnakum law as abtum lam tu'jarū wa-in akhța'tum atsimtum

[Sahl bin Aslam said, "It was Bakr bin Abdullah when he saw an old man, he said: 'This man is better than me, he has been worshiping Allah since

\footnotetext{
27 Al-Isfahani, II:226.

${ }^{28}$ Al-Isfahani, II:227.
} 
before me.' And when he saw the young man he said, 'This man is better than me, I have committed more sins than he did.' He also said, 'You must carry out the orders. If you are right you will be rewarded, and if you are wrong then you are not sinful. And you should stay away from everything that if you are right you will not get a reward and if you are wrong you will sin.' Said, 'What is it?' He said, 'It's bad to think of other people. Because if you are right then you will not get a reward, but if you are wrong then you are sinful'.]

The existence of Bakr al-Muzani is very important as a role model in society, whether as a figure or an ordinary citizen. An example for community leaders is modesty amid their wealth, at the same time feeling that their goodness is still lacking, although they have done a lot of good.

For members of society, this figure is also a mirror, rich, big, and influential people are still ordinary, modest, then why do poor people want to have a disproportionate and self-serving attitude. In short, the example of this figure is important in joint efforts in the community to increase mutual immunity and fight the epidemic that is still hitting. A person with the gift of wealth and then able to be modest and get along with anyone will be a supporter of togetherness in social life.

\section{Cheerful and Joke}

People, in general, have the impression that Sufis are not familiar with cheerfulness and even jokes. Modesty is not synonymous with poverty, there are still many treasures, only wealth does not forget oneself. That is one of the pious traditions of the Sufis.

This character named Muhammad ibn Sirin was referred to by Abu Nu'aim as a unique figure with several inherent traits. In detail, Abu Nu'aim in Hilyat al-Auliyā writed as follows: ${ }^{29}$

$$
\begin{aligned}
& \text { ومنهم ذوالعقل الرصين والورع المتين المطعم للإخوان والزائرين ومعظم الرجاء للمذنبين أبو بكر } \\
& \text { محمد ابن سيرين كان ذا ورع وأمنة وحطة وصيانة كان بالليل بكاء نائحا وبالنهار بساما } \\
& \text { سائحا يصوم يوما ويفطر يوما }
\end{aligned}
$$

wa-minhum dzū 1- 'aqli 1-rașīn wa-l-wara' al-matīn, al-muț 'im li 1-ikhwān wa l-zā 'in̄̄n wa-mu'zim al-rajā 'a li l-mudznibīn abū bakr muhammad ibn sīnīn, kāna dzā wara'in wa-amānatin wa-ḥițatin wa-șiyānatin, kāna bi llaili bukā 'an nā 'ịhan wa-bi l-nahā ri basāman sā 'ị̣ an yașūmu yawman wayufțiru yawman

[some of them were Abu Bakr Muhammad ibn Sirin, who had a calm mind, wara' and steadfast, who loved to feed his brothers and travellers, and raise hope for the sinners. He has piety, trust, protection and maintenance. At

29 Al-Isfahani, II:263-65. 
night he cries a lot to Allah, and during the day he smiles a lot and travels, he fasts a day and breaks his fast.].

Ibn Sirin is told as a person who is cheerful and likes to joke, of course with jokes that are not excessive. As a Sufi figure and often a role model for the community, in addition to his qualified Islamic knowledge, ibn Sirin has the joy of generating optimism in the community.

This testimony of joy was put forward by Habib bin al-Shahid one time when ibn Sirin was teaching. Some of these happy stories were written by Abu Nu'aim as follows: ${ }^{30}$

$$
\text { كان محمد ابن سيرين يتمثل الشعر ويذكر الشيء ويضحك حتى جاء الحديث من السنة }
$$

kāna muhammad ibn sìrin yatamatstsalu al-syi 'ra wa-yadzkuru al-syai'a wa-yadhaku hattō jā'a l-haditsu min al-sunnati kalaha wa-indamma ba'duhu ilä ba'din

[Muhammad bin Sirin once said poetry and mentioned something and then laughed, until when the hadith came from as-Sunnah he frowned and some of them frowned at others].

$$
\text { كان ابن سيرين ربما ضحك حتى يستلقى ويمد رجليه }
$$

kāna ibn sīrin rubbamā ḍahika ḥattā yastalqī wa-yamudda rijlaihi

[Ibn Sirin once laughed on his back and stretched his legs out]

$$
\text { كان ابن سيرين لا يئن على بلاء وربما ضحك حتى تدمع عينه }
$$

kāna ibn sìrin lā ya'innu 'alā balā'in wa-rubbama ḍahika ḥattā tadma'u 'aināhu

[Ibn Sirin never moaned because of a disaster, he even laughed until his eyes watered]

A character named Yusuf bin Athiyah Abu Sahl gave a similar testimony that one day he saw ibn Sirin as a person who joked and laughed a lot. Once, according to Abu Syaudzab's narrative, it is still written on the same page, Ibn Sirin used to joke with his friends, and he once said to his friends, "welcome, O al-mudarfisyinn". The word al-mudarfisyūn is the person who witnesses the corpse and carries it to the grave.

The cheerful and joking nature of the Sufis, aka humorous, is not well known to the public. They get the image that the Sufis are only engrossed in their God, their days are full of dhikr, 'uzlah, and various activities that stay away from the world.

Ibn Sirin represents a unique Sufi character, with his cheerfulness and humor. This is very important to complete the Sufistic teachings about patience, tawakkal,

30 Al-Isfahani, II:272-73. 
and avoiding various heart diseases. When in a society, both the characters and their members are humorous; then many things can be handled jokingly in finding solutions. This includes the existence of a pandemic with a very high level of danger. The tense atmosphere that haunts the community due to a large number of deaths makes people need relaxation with humor, so they don't get confused and get carried away in depression.

\section{Friendly to take hints}

The figure in terms of being friendly to take guidance is Abdullah al-Mursi. This is expressed as part of the principle of a tharīqah, namely the Syadziliyah congregation. The basic principles of the Syadziliyah teachings are stated in alMafā khir as follows: ${ }^{31}$

$$
\text { إن العمدة في طريق الشاذلية الصحبة الصالحة مع الإهتداء والمحبة الصادقة مع الإقتداء }
$$

[inna l-'umdata fi țañqi l-syādziliyyati al-ṣuhbatu al-ṣāliḥatu ma‘a lihtidā 'i wa l-maḥabbatu al-șā diqatu ma'a l-iqtidā 'i]

[In fact, the basic principles in the teachings of the Syadziliyah congregation are good friends to take guidance and true love to imitate]

Good friendship in the tariqa is to seek and take guidance about goodness. A good friendship certainly involves goodness, because the intention in the friendship is also for the good. Meanwhile, true love is love that is based on the spirit of imitation. A tariqa student, for example, when he loves his murshid or teacher, the context of his love is to imitate the teacher's daily life as a whole, at the same time accompanied by sincere devotion. Likewise, a murshid or teacher is required to have a sense of love in guiding spiritually the students. Based on their love for God, the students' perseverance in studying Sufism to seek God's pleasure is firmly embedded in their souls.

In the context of the community movement against the pandemic, Sufi figures who are always friendly to seek guidance and kindness are very relevant. Such a teacher-student relationship becomes a social role model for the community, to always establish friendships and work for hand in hand to face the pandemic. Generally, in society, if someone is infected with the virus, the community's empathy for those who are undergoing self-isolation deserves appreciation. Limited access for survivors who are in self-isolation requires the help of neighbors regarding their daily needs. The movement to help each other meet the basic needs of survivors by the community is identical to the teacher-student love relationship in the tariqa world.

The practice of community life that works together needs to be strengthened in terms of religious values. The Sufistic perspective that teaches togetherness, empathy for helping each other becomes a strengthening of society because what they do is a

31 Abdurrahman ibn Ibad, Al-Mafakhir Al-'Aliyah Fi 1-Ma'Atsir Al-Syadziliyah (Cairo: Maktabah alKhanji, n.d.), 133. 
real embodiment of religious teachings, especially the teachings of Sufism which is the embodiment of Islamic values. Thus, Islamic values become a legitimator for the social practice of the community to be even stronger because it has a legitimacy basis.

\section{Conclusion}

So many Sufi teachings from simple to complex levels encourage strengthening the community to face and fight the Covid 19 pandemic. The data from the Sufi literature show that the teachings are very diverse and well-practiced by Sufis. This shows very strongly that Sufi teachings can be used as concrete examples in the community who are struggling together against the Covid 19 pandemic. Piety, total submission to God, an attitude of accepting existence, far from being greedy and miserly, and various other Sufi teachings become the legitimator of the community movement to respond to the pandemic proportionally and boost their ability to fight it.

\section{Bibliography}

Ach Maimun. "Mahabbah Dalam Tasawuf Rabi 'ah Al-Adawiyah." Millah 3, no. 2 (2004): 172-87. https://journal.uii.ac.id/Millah/article/view/7018.

Al-Attar, Faridudin. Tadzkirat Al-Auliya. Translated by Muhamad al-Asili al-Wastāni Al-Syafi’i. Tehran: Markaz Tahqiqat Kutub li-Ulum 1-Islami, 2008.

Al-Ghazālī, Abu Hāmid. Minhāj Al-'Abiđìn Ilā Jannati Rabb Al-'Alamīn. Cairo: Dār al-Minhāj, 1998.

Al-Isfahani, Abu Nu'aim. Hilyat Al-Auliya Wa-Tabaqat Al-Asfiya. Vol. II. Beirut: Dar al-Fikr li 1-Tiba'a wa 1-Nasyr wa 1-Tawzi, 1996.

Al-Jampesi, Ihsan Muhammad Dahlan. Sirāj Al-Ṭālibīn. Beirut: Dar al-Fikr, 2002.

Al-Sakandari, Ibn Athaillah. Al-Hikam. Beirut: Dar al-Fikr li 1-Tiba'a wa 1-Nasyr, 1987.

Latā 'if Al-Minan. Edited by Abd al-Halim Mahmūd. Beirut: Dār al-Mina, 2007.

Ali, Mohammed Farid. "Contentment ( Qanācah ) and Its Role in Curbing Social and Environmental Problems." Islam and Civilisational Renewal 5, no. 3 (2014): 430-45. https://doi.org/10.12816/0009871.

Arifin, Samsul, and Akhmad Zaini. "Decision of Implementing Uzlah and Gerbat Techniques in Islamic Boarding School as Preparedness Response for Covid-19 Pandemic." Unnes Journal of Public Health 9, no. 2 (2020). https://doi.org/10.15294/ujph.v9i2.38107. 
Bisri, Hasan. "Religious Community Responses to COVID-19: Case Study on Muslim Small Community." International Journal of Psychosocial Rehabilitation 24, no. 8 (2020): 10439-46. https://doi.org/10.37200/IJPR/V24I8/PR281038.

Braddock, Christopher. "Silence Will Change the World: Kierkegaard, Derrida and Islamic Sufism." In The Philosophy of Spirituality, 189-208. Brill, 2019. https://doi.org/10.1163/9789004376311_012.

Daulay, Haidar Putra, Zaini Dahlan, and Chairul Azmi Lubis. "Takhalli, Tahalli Dan Tajalli." Pandawa 3, no. 3 (2021): 348-65. https://doi.org/10.36088/pandawa.v3i3.1334.

Djalante, Riyanti, Jonatan Lassa, Davin Setiamarga, Aruminingsih Sudjatma, Mochamad Indrawan, Budi Haryanto, Choirul Mahfud, et al. "Review and Analysis of Current Responses to COVID-19 in Indonesia: Period of January to March 2020." Progress in Disaster Science 6 (April 2020). https://doi.org/10.1016/j.pdisas.2020.100091.

Febriani, Dyah, Valeryan Bramasta, and Vanissa Noorizqa. "Evaluation of Government Policy Readiness in the Management of the Covid-19 Pandemy Viewed From the Implementation of Dynamic Governance." Research Gate, no. April (2020).

Hidayaturrahman, Mohammad, Husamah Husamah, Sudarman Sudarman, Fitri Yanti, and Ita Rahmania Kusumawati. "Religious Behavior of Indonesian Muslims as Responses to the Covid-19 Pandemic." Al-Adabiya: Jurnal Kebudayaan Dan Keagamaan 16, no. 1 (2021). https://doi.org/10.37680/adabiya.v16i1.704.

Ibad, Abdurrahman ibn. Al-Mafakhir Al-'Aliyah Fi 1-Ma'Atsir Al-Syadziliyah. Cairo: Maktabah al-Khanji, n.d.

Ilyas, Sabrida Muhammad. "Islamic Psychotherapy In The Pandemic Of Covid-19." ENLIGHTEN (Jurnal Bimbingan Dan Konseling Islam) 3, no. 1 (2020). https://doi.org/10.32505/enlighten.v3i1.1581.

Irawan, Bambang, Ismail Fahmi Arrauf Nasution, and Hywel Coleman. "Applying Ibn 'Arabī's Concept of Tajallī: A Sufi Approach to Environmental Ethics." Teosofia: Indonesian Journal of Islamic Mysticism 10, no. 1 (2021). https://doi.org/10.21580/tos.v10i1.7204.

Karni, Awis. "Al-Tasawwuf Fî Indûnîsiyâ; Dirâsah Li Nuskhah Kitâb Matâlib AlSâlikîn Ta'lîf Yûsuf Al-Makâsârî." Studia Islamika 3, no. 2 (1996). https://doi.org/10.15408/sdi.v3i2.810.

Kasdi, Abdurrohman, and Saifudin. "Resilience of Muslim Families in the Pandemic Era: Indonesian Millennial Muslim Community's Response Against COVID-19.” Jurnal Penelitian 17, no. 1 (2020): 81-94. http://ejournal.iainpekalongan.ac.id/index.php/Penelitian/article/view/2781.

Klimová, Daniela, Jakub Styk, Simona Humplíková, Petra Priščáková, and Vanda 
Repiská. "COVID-19 Pandemy-The Global Challenge." Lekarsky Obzor 69, no. 4 (2020): 102-6. https://www.lekarsky.herba.sk/index.php/2020/279-lekarskyobzor-4-2020/867-pandemia-covid-19-celosvetova-vyzva.

Krippendorf, Klaus. Content Analysis: An Introduction to Its Methodology. 2nd ed. Thousand Oaks, CA: Sage, 2004.

Kristeva, Julia. Desire in Language: A Semiotic Approach to Literature and Art. Colombia: Columbia University Press, 1980.

Mukholik, Ayis. "Human Spirituality Phases in Sufism:The Study of Abu Nasr AlSarraj in The Book of Al-Luma'." Teosofia: Indonesian Journal of Islamic Mysticism 6, no. 1 (June 15, 2017): 21-32. https://doi.org/10.21580/tos.v6i1.1699.

Mustakim, Muh., Kana Safrina Rouzi, and Tumin Tumin. "Spiritualization of Child Education in the Qur'anic Sufism Perspective in the Covid-19 Era." International Journal of Islamic Educational Psychology 2, no. 1 (2021). https://doi.org/10.18196/ijiep.v2i1.11132.

Pabbajah, Mustaqim, Nurhidayat Muhammad Said, Faisal, M. Taufiq Hidayat Pabbajah, Hasse Jubba, and Juhansar. "Deauthorization of the Religious Leader Role in Countering Covid- 19: Perceptions and Responses of Muslim Societies on the Ulama's Policies in Indonesia." International Journal of Criminology and Sociology 9 (2020). https://doi.org/10.6000/1929-4409.2020.09.25.

Rajab, Khairunnas. "Maqam Dan Al-Ahwal Dalam Tasawuf." Usuluddin 25 (2007): 56. https://ejournal.um.edu.my/index.php/JUD/article/view/5078.

Salleh, Kamarudin, Zaizul Ab Rahman, Ahmad Yunus Mohd Noor, and Mohd Izhar Ariff Izhar Mohd Kashim. "Resilience and Patience (Sabr) in Islamic View When Observing the Movement Control Order (MCO) during the Covid 19 Pandemic." International Journal of Psychosocial Rehabilitation 24, no. 1 (2020): 5485-97. https://doi.org/10.37200/IJPR/V24I1/PR200654.

Sastra Yudha. "Tilik Respon Awal Pemuka Agama Terhadap Covid-19 Bersama STF." http://rdk.fidkom.uinjkt.ac.id/, July 2021. http://rdk.fidkom.uinjkt.ac.id/index.php/2021/07/02/tilik-respon-awal-pemukaagama-terhadap-covid-19-bersama-stf/.

Thomas, Justin, and Mariapaola Barbato. "Positive Religious Coping and Mental Health among Christians and Muslims in Response to the Covid-19 Pandemic." Religions 11, no. 10 (2020): 1-13. https://doi.org/10.3390/rel11100498. 